\title{
Differences in Ocb-I and Ocb-0 Based on Gender: A Case of Insurance Agents in Indonesia
}

\section{Bernadeta Irmawati and Berta Bekti Retnawati}

Department of Management, Faculty of Economics and Business, Soegijapranata Catholic University

\section{Abstract}

This article aims to know if OCB-I and OCB-O differ according to gender. An insurance agent whose function is of a salesperson plays an important role in the organization because it can connect the company with the community. Insurance agents with OCB both OCB-I and OCB-O will be able to increase organizational effectiveness. Data were collected using a questionnaire from 50 either general or life insurance agents in Central Java. The analysis with $t$-test showed that there were no differences in OCB-I

Corresponding Author: Bernadeta Irmawati Irmawati_b@unika.ac.id Received: 29 August 2018 Accepted: 18 September 2018 Published: 11 November 2018 Publishing services provided by Knowledge $\mathrm{E}$

(c) Bernadeta Irmawati and Berta Bekti Retnawati. This article is distributed under the terms of the Creative Commons Attribution License, which permits unrestricted use and redistribution provided that the original author and source are credited.

Selection and Peer-review under the responsibility of the ICOI-2018 Conference Committee. and OCB-O based on Gender.

Keywords: OCB-I, OCB-0, gender

\section{Introduction}

The roles of human resources, especially in the management of sales organizations with a fleet of sales force are very important (Piercy et al., 2006). First, the agent becomes a marketing tool that connects the company to consumers. Second, the sales organization is responsible for many marketing expenses and revenues in most companies. In fact, for most companies in industrial markets, the direct selling cost is far beyond the spending on media advertising or other forms of sales promotion. Third, in this new millennium, sales organizations are faced with a number of important challenges stemming from environmental alter that dramatically change the way salespeople and sales managers understand, prepare and complete their jobs (Piercy et al., 2006; Baldauf and Cravens, 2002)

The fundamental role of sales organizations and critical challenges in this competitive is crucial for sales managers and companies to analyze the various issues related to salesperson performance. Many researchers in marketing and human resource identify what can affect salesforce performance. they can reach the target of the company (Baldauf and Cravens, 2001). The growth of the insurance industry in Indonesia can be 
identified from the growth of insurance premiums of especially life insurance, which grew by $37.76 \%$ in 2017. According to the Financial Services Authority (0JK), the life insurance industry grew double digits until the third quarter of 2017 while general insurance had increased by $19.38 \%$. This shows that the Insurance business has been growing.

One role that cannot be separated from the insurance business is the Insurance Agent whose a salesperson. This profession requires the sales force to move closer to prospective individual and corporate customers. Their job is as corporate ambassadorssomeone who is trusted to represent the company to promote, offer, and explain insurance products professionally, credibly and with integrity. Along with the development of the insurance business, and the increasing of public awareness on the importance of insurance in Indonesia, the insurance marketing system (agency) is increasingly demanded to work with higher quality toward better performance (Retnawati and Purwanto, 2004).

Insurance agents position themselves as long-term financial consultants to customers. Agents should be able to provide the best possible consultation on what the prospective customer really needs, so that they can get benefits on buying an insurance policy. The duty of the insurance agent does not end when the purchase by a customer is done and the insurance policy is issued. The agent shall keep providing consultations and fostering good relationship with the customer. This is very important, because customer satisfaction will have a good impact on the agent, building trust with the prospective customer (Rahim, 2013).

An agent is a front liner in the insurance business with an important role for the company's performance. The insurance agent expectedly participates actively in conducting the behavior covered by OCB (Organizational Citizenship Behavior). OCB is an extra individual behavior which is beyond the main task and does not have correlation with the reward system that applies in an organization but is a willingness to increase organizational effectiveness (often called as extra role)

William and Anderson (1991) divides the OCB into two dimensions: OCB-I (Organizationship Citizenship Behavior toward Individual) and OCB-O (Organizational Citizenship Behavior toward Organizations). It is known in many studies, that a person performing OCB-O depends heavily on the company policy or is heavily dependent on the organizational context (Lavelle et al., 2009), while doing OCB-I is more dependent on personal relationships.

Allen's research (2006) suggests that gender-like stereotypes in the work environment occur, in which organizational rewards for female and male employees are often 
different. While Akinbode (2011) suggests that female do more OCB than male, where female are more willing to help other people and are more generous (Dewi, 2016). The purpose of this research is to know if OCB-I and OCB-O differ according to gender.

\section{Literature Review}

OCB or Organizational Citizenship Behavior is behavior beyond the formal obligations or job descriptions that is not rewarding (Robbins and Judge, 2008) but capable in supporting organizational effectiveness. Research on OCB began in the early $1980 \mathrm{~s}$ by Bateman and Organ (1988). There are two dimensions of employee behavior: do what should do and help others (altruism). The concept undergoes several transformations into five dimensions within the OCB: altruism, conscientiousness, sportsmanship, courtesy, and civic virtue.

First, altruism is a voluntary act committed by a person or group of people to help others without expecting anything in return, except the feeling of doing good deeds. Second, conscientiousness, refers to a more cautious attitude and listening to conscience. The existence of such behavior may indicate that workers have accepted and obeyed the rules and procedures that exist within the company. So when it is viewed in the context of a company the existence of this behavior would be very profitable, because workers with high conscientiousness will have a good attitude compared to the other colleagues by showing better obedience to the regulations and procedures of the company. Third, courtesy can be described from a form of action aimed at preventing emergence of problems, acting politely, sharing and exchanging thoughts on completing the task, etc. Fourth, sportsmanship can be seen from the aspect of tolerance and complaints (complain) from individuals in their work. Individuals with high sportsmanship attitudes will pay great attention to detail in their work, can do their work fairly and complain slightly, and adapt to the situation and work environment. In the context of a company this attitude will certainly be very profitable, because workers will easily adapt to the changes that exist in the company. Fifth, civic virtue is shown by the behavior of fully participating (self-involvement) and of more attentive to the company where the individual it works. Individuals with high civic virtue will pay great attention to the company's interests. It can be demonstrated by the individual's always playing an active role in all activities that exist in the company, such as employee training, workshops, and so on, attention to the important information either from outside or from inside the company that can benefit the company. 
The concept of OCB-I and OCB-O was originally developed by Williams and Anderson (1991), which states that OCB-I is an individual-directed behavior and OCB-O is an organizational-directed behavior. William and Anderson (1991) classified the five dimensions of Organ's (1988) into OCB-I comprising of altruism and courtesy and OCB0 comprising of conscientiousness, civic virtue and sportsmanship.

OCB-I is an effort and concern to assist new colleagues in doing their work, provide assistance to co-workers whom face work-related problems, help and give assistance and attention to anything that indirectly affects organizational effectiveness (Lee and Allen, 2002; Williams and Anderson, 1991). Meanwhile OCB-O encourages employees to do $O C B$, for particularly the reason of the desire to contribute to the organization in the forms of offering ideas to improve functioning of the organization, implementing innovative ideas that can directly provide benefits to the department, other parties (organization or superior), and morals of the society. Aryee et al. (2002), Finkelestein (2006), and Harper and College (2015) added some variables to William and Anderson's (1991) OCB-I and OCB-O with motivation, task clarity, leadership, organizational commitment associated with individual, group and organizational performance.

There is a general assumption that OCB behaviors differ by gender. Gender can affect how an individual relates to a co-worker whom provides social support, opportunities and information. Research shows that there is a stereotype which women is more altruistic than men, in including participation in various activities and organizational existence (Punia and Shyam, 2017)Akinbode (2011) in his research suggested that women do more OCB than men where women are considered more willing to help others and be more generous (Dewi, 2016, Heilman and Chen, 2005, Punia and Shyam, 2017). Piercy et al., (2012) in his research on sales managers stated that a women led sales team was reported significantly higher OCB levels, in six of seven measured dimensional constructs and in the overall OCB index. The only exception to this result was in the conscientiousness dimension, where there was no difference between teams with the sales manager which differs by gender

The hypothesis proposed in this research are:

H1: There is a difference of OCB-I on insurance agent based on gender

$\mathrm{H} 2$ : There is a difference of OCB-O on insurance agent based on gender 


\section{Methods}

The object of this study was the insurance agents. Methods of data collection were questionnaires and interviews. The questionnaires were sent to 100 respondents from both general and life insurance. Sample criteria was agent who have joined the insurance company for at least 1 year. of 60 questionnaires that were returned, only 56 complied with the criteria and only 50 were complete. The interview was conducted to 10 agents.

Measurements of OCB-I and OCB-O variables were based on William and Anderson's (1991) and Grasiawati's (2016). The questionnaire used 5-scale Likert ranging from 1 (strongly disagree) to 5 (strongly agree). OCB-I is a behavior that leads to an individual to help colleagues and was measured using item of helping others having a lot of works, taking time to listen to other people's problems, passing information to other employees. While OCB-O is a behavior that is directed at the organization was measured to giving notice when unable to come to work, adhering to informal maintaining and protecting organizational property. The data analysis technique used was ' test that was to test whether there is OCB-I and OCB-O differ according to gender. The validity test results indicated that the OCB-I and OCB-O items were valid. The reliability test results showed that the questionnaire was reliable with OCB-I $=0.652$ and OCB-O $=0.703$.

\section{Results and Discussion}

In general, insurance companies are divided into two, namely general insurance companies and life insurance companies. Products sold by insurance companies differ from each other, for general insurance companies: the products were for example insurance for under the fire, vehicles, and buildings, etc. Meanwhile life insurance companies offered the insurance individual protection insurance for health, work accident, education and investment. The Insurance Agents as the front liners of the insurance companies did not have the status of permanent employees, worked with unlimited space and time, and even set their own salary based on the number of clients and types of insurance products that could be sold. Every insurance agent can perform their duties after awarded a professional certification as an agent and joined an insurance company. Here is an overview of insurance agent respondents. 
TABLE 1: General overview of respondent.

\begin{tabular}{|l|c|c|c|}
\hline & \multicolumn{3}{c}{ Insurance Agent } \\
\hline \multirow{2}{*}{ Gender } & Male & $f$ & $\%$ \\
\hline \multirow{2}{*}{ Age (Year) } & Female & 27 & 54 \\
\hline & $25-35$ & 18 & 47 \\
\hline Education & $36-45$ & 17 & 34 \\
\hline & $46-55$ & 15 & 30 \\
\hline Work Length & High School & 14 & 28 \\
\hline & Diploma & 14 & 28 \\
\hline Source: Processed Primary Data, 2017. & 22 & 44 \\
\hline
\end{tabular}

Based on the aforementioned data, it is known that men respondents were 27 ( $54 \%$ ) and women were $23(47 \%)$. Majority of the respondents were on age of $25-50$ years old, had the education level of $\mathrm{S}_{1}(44 \%)$, and had the work length of $1-5$ years (50\%).

Based on the $t$-test, the following results were obtained:

TABLE 2: Total, mean and Sig. $t$-value of female and male agents on OCB scale.

\begin{tabular}{|c|c|c|c|c|}
\hline & GENDER & TOTAL & MEAN & Sig. (2-tailed) \\
\hline OCB-I & FEMALE & 23 & 4.0178 & 0.928 \\
\hline & MALE & 27 & 4.0252 & \\
\hline OCB-O & FEMALE & 23 & 3.3026 & 0.993 \\
\hline
\end{tabular}

This research is based on OCB-I and OCB-O Concepts developed by Williams and Anderson (1991) to insurance agents in Central Java

Based on Table 2 the hypothesis stating that there is gender-based differences in OCB-I is rejected with sig.0.348, meaning there is no difference in OCB-I between female and male insurance agents. This suggests that both female and male insurance agents showed no different behavior in helping others in work and in behaving decently. Based on the mean of OCB-I, there was no significant difference between female (4.0178) and male (4.0252). it means that both female and male agents showed OCB-I behavior that is above average (2.5). This indicates that they helped others who were absent and had workloads, assisted the supervisor with his/her work (when not asked), gladly helped new employees. 
Based on the interviews on 10 respondents, It can be concluded that as they claimed they had reached the individual performance as required. However they still helped each other in the case of an agent was having problems in dealing with clients or exchanging information related to the needs of clients on either life or general insurance services. The case happened very often was when a client of life insurance required information on general insurance, the agent would then ask for the relevant information to the colleagues.

The second hypothesis is that there is a gender-based OCB-O difference was also rejected with sig.0.993, meaning that there is no OCB-O difference in both male and female insurance agents. This suggests that both male and female insurance agents have no differences in compliance with organizational rules, and are responsible for the work. Based on the mean of OCB-O, there was no significant difference between female (3.3026) and male (3.3033) it means that both female and male agents showed OCB-O behavior that is above average (2.5). This indicates that they gives notice when unable to come to work, offering ideas to improve functioning of the organization, implementing innovative ideas that can directly provide benefits to the department, other parties (organization or superior). Based on the interviews with the agents, it is known that they did not need to come to the office every day. Some companies required the agents to come twice a week for job evaluation, and some others required them to come every morning for briefing or consultations and afterward they can work flexibly according to their respective targets.

The results of this study are different from those of previous research such as Dewi's (2016) and Punia and Shyam's (2017). This suggests that both male and female insurance agents are willing to help co-workers and participate in their organizations. Indeed the work of the insurance agent is relates more to the supervisor than to the co-workers. The insurance agents may meet their co-workers only on regular meetings. Works in insurance are more independent than those in office.

\section{Conclusions}

The stereotype that work is dominated by a particular gender does not occur in every work environment. It is clear that the insurance agents work more outdoor than in the office. They have to visit clients for possibly more than once a day. The results showed that there were no differences in OCB-I and OCB-O if the insurance agents based on gender. 


\section{Acknowledgment}

The authors would like to thank the Indonesia General Directorate of Higher Education and the agents of general insurance and life insurance for participating in the research.

\section{References}

[1] Allen, T. D. (2006). Rewarding good citizens: The relationship between citizenship behavior, gender, and organizational rewards. Journal of Applied Social Psychology, vol. 36, no. 1, pp. 120-143. Retrieved from http://doi.org/10.1111/j.0021-9029.2006. 00006

[2] Aryee, S., Budhwar, P. S., and Chen, Z. X. (2002). Trust as a mediator of the relationship between organizational justice and work outcomes: Test a social exchange model. Journal of Organizational Behavior, vol. 23, no. 3, pp. 267-285.

[3] Baldauf, A. and Cravens, D. (2002). The effect of moderaotor. European Journal of Marketing, vol. 36, no. 11/12, pp. 1367-1388.

[4] Cameron, S. M. and Nadler, J. T. (2013). Gender roles and organizational citizenship behaviors: Effects on managerial evaluations. Gender in Management: An Internotional Journal, vol. 28, no. 7, pp. 380-399.

[5] Dewi, R. M. and Perdhana M. S. (2016). The role of gender, age, and level of education on organizational citizenship behavior. Diponegoro Journal of Management, vol. 5, no. 2, pp. 1-9. Retrieved from http://ejournal-s1.undip.ac.id/index.php/dbr ISSN

[6] Finkelstein, M. A. (2006). Dispositional predictors of organizational citizenship behavior: Motives, motive fulfillment, and role identity. Social Behavior and Personality, vol. 34, no. 6, pp. 603-616.

[7] Grasiaswaty, N., Juwita F. R., and Setyasih, N. (2016). Adaptation of measuring Organizational Citizenship Behavior (OCB) with peer review in Indonesia. The 2nd ASEAN Seminar on Psychology and Humanity (c) Psychology Forum UMM.

[8] Harper, P. J. and College, M. (2015). Exploring forms of organizational citizenship behaviors (OCB): Antecedents and outcomes. Journal of Management and Marketing Research, vol. 6, pp. 1-16.

[9] Piercy, N. F., Cravens, D. W., and Lane, N. (2012). Sales manager behavior-based control and salesperson performance: The effects of manager control competencies and organizational citizenship behavior. Journal of Marketing Theory and Practice, vol. 20, no. 1, pp. 7-22. 
[10] Piercy, N. F., Cravens, D. W., Lane, N., et al. (2006). Driving organizational citizenship behaviors and salesperson in-role of management control and perceived organizational support. Academy of Marketing Science, vol. 34, no. 2, pp. 244-262.

[11] Piercy, N. F., Cravens, D. W., Lane, N., et al. (1998). Salesforce Performance and Behaviour-Based Management Processes in Business-To-Business Sales.

[12] Punia, A. P. and Shyam, R. (2017). Gender difference in of Organisational Behaviour (OCB) and motives underlying OCB. Psychological Behavioral Science International Journal, vol. 4, pp. 1-5.

[13] Rahim, H. (2013). Optimism of Indonesian insurance growth: Projected five-year development optimisme (2014-2018). Jurnal Asuransi dan Manajemen Risiko, vol. 1, no. 2, pp. 21.

[14] Robbins, S. P. and Judge, T. A. (2013). Organizational Behavior. New York, NY: Prentice Hall.

[15] Williams, L. and Anderson, S. (1991). Job satisfaction and organizational commitment as predictors of organizational citizenship and in-role behaviors. Journal of Management, vol. 17, pp. 601-617. 